\title{
Plant food resources exploited by Blue-and-Yellow Macaws (Ara ararauna, Linnaeus 1758) at an urban area in Central Brazil
}

\author{
Santos, $A A .^{a *}$ and Ragusa-Netto, J. ${ }^{b}$ \\ aUniversidade Federal de Mato Grosso do Sul - UFMS, Av. Ranulpho Marques Leal, 3484, \\ Distr. Industrial, CEP 79620-080, Três Lagoas, MS, Brazil \\ bDepartamento de Ciências Naturais, Câmpus Três Lagoas, Universidade Federal de Mato Grosso do Sul - UFMS, \\ CP 210, CEP 79610-100, Três Lagoas, MS, Brazil \\ *e-mail: lelex.santos@gmail.com
}

Received: December 20, 2012 - Accepted: March 21, 2013 - Distributed: May 31, 2014

(With 3 figures)

\begin{abstract}
In this study, we described the food plants available to Blue-and-Yellow Macaws (Ara ararauna), its feeding habits and the relationship between these parameters with feeding niche breadth. We established four transects, each one $12 \mathrm{~km}$ long, to sample fruiting plants and the feeding habits of this macaw (monthly $40 \mathrm{~h}$, of observations), at the urban areas of Três Lagoas (Mato Grosso do Sul, Brazil). During all studied months, macaws foraged for palm fruits, mainly Syagrus oleracea and Acrocomia aculeata fruit pulp, both available all year, as well as Caryocar brasiliense and Anacardium occidentale seeds, in the wet season. The year-round feeding activity of macaws suggests Três Lagoas city as an adequate feeding area. The permanent availability of plant food resources, potentially, resulted from the diverse fruiting patterns of exotic and, mainly, native plant species, which provided a variety of suitable fruit patches.
\end{abstract}

Keywords: frugivory, Psittacidae, Ara ararauna, urban ecosystems, feeding ecology.

\section{Plantas alimentares exploradas pela Arara Canindé (Ara ararauna, Linnaeus 1758) em uma área urbana do Brasil Central}

\begin{abstract}
Resumo
Neste estudo, nós descrevemos as plantas alimentares disponíveis para Arara-Canindé (Ara ararauna), sua atividade alimentar, bem como a relação desses parâmetros com a amplitude do seu nicho alimentar. Para tanto, estabelecemos quatro trajetos, cada um com $12 \mathrm{~km}$, dispersos na área urbana de Três Lagoas (Mato Grosso do Sul, Brasil). A partir deles amostramos, mensalmente durante $40 \mathrm{~h}$, as espécies vegetais que frutificavam e a atividade alimentar dessa ave. As araras exploraram frutos em todos os meses do ano e consumiram principalmente frutos comuns e nutritivos. Entre os itens mais explorados pelas araras estiveram as sementes de Anacardium occidentale e Caryocar brasiliense, cuja frutificação ocorreu durante a estação chuvosa, bem como a polpa dos frutos das palmeiras Syagrus oleracea e Acrocomia aculeata, que frutificaram o ano todo. A presença de araras forrageando todos os meses em Três Lagoas sugere a adequação dessa área urbana como local de alimentação. A disponibilidade de recursos alimentares ao longo do ano, potencialmente, decorreu da combinação da variedade dos padrões de frutificação em espécies vegetais exóticas e, sobretudo, nativas que proporcionaram oferta abundante e variada de recurso alimentar.
\end{abstract}

Palavras-chave: frugivoria, Psittacidae, Ara ararauna, ecossistemas urbanos, ecologia alimentar.

\section{Introduction}

The Blue-and-Yellow Macaw (Ara ararauna, Linnaeus 1758) occurs in southern Central America and in tropical South American countries, where it is yet locally common (Collar, 1997). Unlike most congeners, which live in Neotropical forest, the Blue-and-Yellow Macaw also inhabits semi-open areas. In this respect, their habitats may range from dry savannas to tall rain forests (Sick, 1997; Collar, 1997). Particularly in Brazil, it is widely distributed mainly through Amazonia, Cerrado and Pantanal (Sick, 1997; Collar, 1997). However, as several other parrot species, the Blue-

and-Yellow Macaw is declining (Bird Life International, 2000). Therefore, a major concern is the scarce knowledge on basic ecology data of this species, mainly those data potentially related to the causes of their decline. As many large vertebrates, the Blue-and-Yellow Macaw has been mostly affected by the intense urbanization process, habitat clearing, alteration, or degradation, as well as collection for the pet trade or hunting (Novaro et al., 2000; Bodmer and Lozano, 2001). In fact, their former distribution has been drastically reduced due to the accelerated clearing 
of Brazilian Cerrado for pastures and agriculture areas (Ratter et al., 1997; Carvalho et al., 2009). In some regions, as southwestern Brazil, the Blue-and-Yellow Macaw was recently listed as critically endangered (Antunes, 2009a, b). Even then, despite of its decline around heavily anthropized areas, this parrot has been resilient to human activities (Ridgely and Greenfield, 2001).

The Blue-and-Yellow Macaw is among the largest Psittacidae (Collar, 1997; Sick, 1997). In this respect, it is reported as an important pre-dispersal seed predator (Tubelis, 2009; Ragusa-Netto, 2006, 2011). Up to now, data on their feeding habits mostly results from circumstantial feeding records across their wide distribution area (Forshaw, 1989; Sick, 1997; Collar, 1997). The consumption of large seeds either at forests or savannas has been a major trend in their diet (Trivedi et al., 2004; Haugaasen and Peres, 2005; Tubelis, 2009; Ragusa-Netto, 2006, 2011), as well as the use of palm fruits (Roth, 1984; Sick, 1997; Oehler et al., 2001). The Blue-and-Yellow Macaw also feeds on items as fruit pulp, arils, nectar, flowers, and leaves (Forshaw, 1989; Sick, 1997; Collar, 1997). Therefore, it is a feeding generalist, which roosts and breeds at palm stands, mainly Mauritia stands (Sick, 1997; Collar, 1997; Brightsmith and Bravo, 2006; Renton and Brightsmith, 2009). Potentially, their population decline has resulting, at least in part, from the reduction of food sources mostly due to the fragmentation of feeding areas (Carvalho et al., 2009). Consequently, as fruit patches are progressively becoming scattered arranged within a matrix of pastures and crop areas, Blue-and-Yellow Macaws might incur in severe foraging costs (Graham, 2001) while moving to impoverished feeding areas (Ragusa-Netto, 2006). However, as these parrots often experience food shortage due to the erratic seasonality of fruiting patterns (Bullock and Solís-Magallanes, 1990; Funch et al., 2002; RagusaNetto and Silva, 2007), they are able to move over large areas searching for suitable food sources (Renton, 2001; Ragusa-Netto, 2005, 2006). In fact, for nomadic frugivores the sites of a habitat mosaic could be important in distinct periods of the year (van Schaik et al., 1993; Renton, 2001; Ragusa-Netto, 2004, 2007a, 2008b; Melo et al., 2009).

Recently, Blue-and-Yellow Macaws have been recurrently recorded at anthropized areas including urban ones, mostly in Central Brazil (A. Santos pers. observ.). In fact, this macaw has foraged at modified landscapes within habitat mosaics of natural feeding areas (Ragusa-Netto, 2006; Marsden and Wright, 2004). However, the factors related to the presence of this macaw at cities are poorly known. An important approach to plan the management and conservation of a declining species is the detailed documentation of their feeding habits according to the habitats used across its distribution range. As Blue-and-Yellow Macaws are often present at cities, the examination of their activities in these sites is needed. Taking into account the potential use of urban areas for feeding purposes, in this study we investigated the exploitation of food resources by Blueand-Yellow Macaws at the urban area of Três Lagoas (Mato Grosso do Sul, Brasil), to describe its feeding habits at this modified landscape along the year. Additionally, we analysed the relationship between its feeding activity and plant species availability, as well as the relationship between these parameters with feeding niche breadth.

\section{Material and Methods}

Study area. This study was conducted from April/2007 to March/2008 at the municipality of Três Lagoas (Mato Grosso do Sul State, Brazil; 51 ${ }^{\circ} 48^{\prime} \mathrm{W}, 20^{\circ} 46^{\prime} \mathrm{S}$, altitude $340 \mathrm{~m}$ ). The climate is seasonal with $1400 \mathrm{~mm}$ average annual rainfall ( $70 \%$, wet season). Mean annual temperature lies around $24^{\circ} \mathrm{C}$ in the wet and $17^{\circ} \mathrm{C}$ in dry season. The vegetation surrounding the urban area includes a mosaic of pasturelands with cerrado remnant trees, cerrado remnants, and seasonal forest in which Blue-and-Yellow Macaws are apparently common (Ragusa-Netto, 2006). The urban vegetation itself is variable, a typical feature of urban areas due to land use and social context (Pickett et al., 2001). In this respect, exotic plant species are often present in central areas, mainly in gardens and squares, whereas native tree species are common in suburban areas in vacant lots and backyards of residences. Among common exotic species at Três Lagoas are: Syzigium cumini (Linn.), Roystonea oleraceae (Jacq.) O. F. Cook., Mangifera indica (Linn.), Persea americana (Mill.), Psidium guajava (Linn.), Musa paradisiaca (Linn.), while common native species are: Syagrus oleraceae (Mart.) Beccari, Caryocar brasiliense (Cambess.), Anacardium occidentale (Linn.), Cecropia pachystachya (Trécul.), Inga laurina (Sw.) Willd. and Copaifera langsdorffii (Desf.).

Plant species availability and feeding activity of macaws. To sample plant food resources availability and consumption by Blue-and-Yellow Macaws across Três Lagoas, we included both urban and suburban areas. Therefore, we established, with the aid of a local map, four $12 \mathrm{~km}$ long transects, located at least $3 \mathrm{~km}$ apart from each other. Such procedure was adopted to sample plants, which were located in public areas like gardens and squares, as well as backyards and residences as representative as possible. Monthly, we walked each transect by $10 \mathrm{~h}$ (see below) searching for fruiting trees and, whenever we spotted a tree bearing fruits we recorded the specie, location, and date. However, only those fruiting species consumed by Blue-and-Yellow Macaws were analysed and comprised the monthly index of plant species availability. This index resulted from the monthly total of species exploited by macaws. We identified plant species by comparison with samples in the herbarium at the Universidade Federal do Mato Grosso do Sul (Campus Três Lagoas); nomenclature folowed Lorenzi (1994; 1998).

We sampled food resources consumption by Blue-andYellow Macaws through direct observations, with the aid of an $8 \times 40$ binoculars, while walking the same transects described above. Blue-and-Yellow Macaws may spent prolonged periods (up to $10 \mathrm{~min}$, Ragusa-Netto, 2006) foraging at a given crown. To avoid resampling them feeding on a specific food source during an observation period, 
we walked the trails only in one direction. Also, we used only initial, instead of sequential observations of feeding Blue-and-Yellow Macaws to assure the independence among feeding samples, and also because it can be assumed that they were equally likely to be seen feeding on any conspicuous food source (Hejl et al., 1990). To sample feeding birds each one of us monthly walked a different transect by a total of $10 \mathrm{~h}$ ( $40 \mathrm{~h}$ of observation every month, from April/2007 to March/2008), from 07:00-10:00 $\mathrm{h}$ and from 16:00-18:00 $\mathrm{h}$ during the dry season, and from 06:00-9:00 $\mathrm{h}$ and from 16:00-18:00 $\mathrm{h}$ during the wet season, periods of intense parrot activity (Marsden, 1999). Whenever Blue-and-Yellow Macaws were detected foraging, we recorded: a) the number of individuals, b) plant species consumed, c) part eaten, d) data and time. Then, as Blue-and-Yellow Macaws were not individually marked, we used the feeding records to avoid pseudoreplication. This conservative data for the analyses consisted only of the number of times a given food item was consumed, regardless of the number of feeding Blue-and-Yellow Macaws, time they spent feeding and amount of food ingested. We also used the feeding records to calculate the frequency of food species consumed by macaws (Table 1). However, to improve the analysis on the extent of food source use, we provided the number of feeding Blue-and-Yellow Macaws together with the proportion of every food item used by them (Table 1).

Analysis. We used the non-parametric Spearman Rank Correlation test to analyse the relationship between plant species availability and Blue-and-Yellow Macaws feeding activity, as well as the relationship between these parameters and feeding niche breadth. Taking into account the generalist feeding habits of macaws, we evaluated the range of its diet using Levin's niche breadth index. We adopted this index as it considers only the proportional use of food items without to incorporate food resource abundance, which was not sampled in this study. Hence, values close to 0 indicate specialized diet and values closed to 1 indicate a broad diet. Niche breadth values were calculated monthly. We grouped plant species according to its potential fruiting pattern: asynchronous, when they bore fruits unpredictably during the year; multiple, when they bore fruits more than once in the year and; seasonal, when they bore fruit only once in the year (Milton et al., 1982; Henderson, 2002). In seasonal areas fruiting pattern fluctuates exhibiting short periods of pronounced fruit production followed by abrupt declines (Justiniano and Fredericksen, 2000; Funch et al., 2002; Ragusa-Netto and Silva, 2007). Hence, in the course of a season fruit production fluctuations have influence on frugivores abundance and feeding activity (van Schaik et al., 1993). Then, considering the potential intra-seasonal changes in fruit production (Renton, 2001; Ragusa-Netto, 2007b, 2008b), we divided the year in four distinct periods which were: the late wet season (January-March), the early dry season (April- June), the late dry season (July-September), and the early wet season (October-December; Ragusa-Netto, 2008a, 2010). To analyse the proportional use of native or exotic fruits, we compared the number of feeding records on each fruit type using Chi-square test. As many plant species might produce fruits in more than one season, we used Chi-square contingency analysis to test for differences either in the number of feeding records on native/exotic fruits or fruits with different fruiting patterns during the four periods of the year. In a contingency table rows represent the different states of one nominal variable, columns represent the states of another nominal variable, and cells contain the counts of occurrences of that specific state (row, column) of the two variables. The significance of association between the two variables (based on chi-squared) is then given, with $p$ values from the chi-squared distribution. The contingency table analysis then gives information on whether the two variables are associated. We perform those analyses in order to explore differences in the use of food resources irrespective of their abundance and diversity in the urban area. Then, as these parameters were not assessed we made the comparisons without the intent to infer Blue-and-Yellow Macaws preference. In these analyses we also took as a replicate the feeding records.

\section{Results}

Plant species availability and its use by Blue-and-YellowMacaws. We recorded a total of 30 fruiting species in the urban area. However, macaws made no use of 9 species. The number of plant species available to Blue-and-Yellow Macaws varied seasonally. Major declines occurred both in April and in October when only four species bore fruits. Conversely during the late dry season, in August, 12 fruit species were available to macaws (Figure 1a). In the early dry season Qualea grandiflora, and Syagrus oleracea bore important fruits, while Inga laurina, Acrocomia aculeata, Psidium guajava, Cocos nucifera, S. oleracea, and $Q$. parviflora did the same in the late dry season. On the other hand, Anacardium occidentale, Caryocar brasiliense, and $A$. aculeata were fruiting in the early wet season. Finally, P. guajava, S. oleracea, C. brasiliense and $Q$. grandiflora bore important fruits in the late wet season (Figure 1a).

We documented a total of 234 feeding records in urban areas of Três Lagoas. A large number of individual fed on available food resources both in the dry $(42 \%$ of feeding records), and in the wet season (58\% of feeding records; Table 1). During the dry season Blue-and-Yellow Macaws monthly fed on a minimum of four (April), and a maximum of 12 (August) fruit species. They exploited from five to seven plant species in the other months. In this period they often fed on A. aculeata (21 feeding records), Q. grandiflora (17), S. oleracea (10), P. guajava (3), H. stigonocarpa (5), Q. parviflora (5; Table 1). On the other hand, during the wet season Blue-and-Yellow Macaws exploited from four (October) to six fruit species (November, Figure 1a). Despite of the reduced number of fruit species monthly exploited in this period, a major feeding peak occurred (October and November) when macaws extensively fed on $C$. brasiliense (55 feeding 
Table 1. Plant species, origin, fruiting pattern, items consumed, and feeding records and the number of the Blue-and-Yellow Macaw (Ara ararauna), feeding at the urban area of Três Lagoas (State of Mato Grosso do Sul, Brazil; $\mathrm{A}=$ aril, $\mathrm{P}=$ fruit pulp, and $\mathrm{S}=$ seed; $\mathrm{N}=$ native, $\mathrm{E}=$ exotic; $\mathrm{Se}=$ seasonal, $\mathrm{As}=$ asynchronous, $\mathrm{Ml}=$ multiple).

\begin{tabular}{|c|c|c|c|c|c|c|}
\hline Plant taxa & Origin & $\begin{array}{l}\text { Fruiting } \\
\text { pattern }\end{array}$ & Items & $\begin{array}{l}\mathrm{N}^{\circ} \text { of feeding } \\
\text { records (\%) }\end{array}$ & $\begin{array}{c}\mathrm{N}^{\circ} \text { of feeding } \\
\text { macaws }(\%)\end{array}$ & Months \\
\hline \multicolumn{7}{|l|}{ Anacardiaceae } \\
\hline Anacardium occidentale (Linn.) & $\mathrm{N}$ & $\mathrm{Se}$ & $\mathrm{S}$ & $29(25)$ & $189(25.8)$ & $\begin{array}{l}\text { May, Aug, Sept, } \\
\text { Oct, Nov, Dec }\end{array}$ \\
\hline Mangifera indica (Linn.) & E & $\mathrm{Se}$ & $\mathrm{P}$ & $1(0.42)$ & $2(0.27)$ & Dec \\
\hline Spondias dulcis (G. Forst.) & E & $\mathrm{Se}$ & $\mathrm{P}$ & $1(0.42)$ & $5(0.68)$ & Feb \\
\hline \multicolumn{7}{|l|}{ Arecaceae } \\
\hline Elaeis guineensis (Jacq.) & E & As & $\mathrm{P}$ & $1(0.42)$ & $2(0.27)$ & June \\
\hline $\begin{array}{l}\text { Roystonea oleracea (Jacq.) O. F. } \\
\text { Cook. }\end{array}$ & $\mathrm{E}$ & As & $\mathrm{P}$ & $1(0.42)$ & $2(0.27)$ & Aug \\
\hline Acrocomia aculeata (Jacq.) & $\mathrm{N}$ & As & $\mathrm{P}$ & $31(13.2)$ & $90(12.3)$ & $\begin{array}{l}\text { May, June, July, } \\
\text { Aug, Sept, Dec, } \\
\text { Jan }\end{array}$ \\
\hline Cocos nucifera (Linn.) & E & As & $\mathrm{S}$ & $3(1.2)$ & $15(2)$ & Aug \\
\hline Mauritia flexuosa (L. f.) & $\mathrm{N}$ & As & S & $1(0.42)$ & $2(0.27)$ & Apr \\
\hline Syagrus romanzoffiana (Cham.) & $\mathrm{N}$ & As & $\mathrm{P}$ & $2(0.85)$ & $7(0.9)$ & Jan, Aug \\
\hline Syagrus oleracea (Mart.) Beccari & $\mathrm{N}$ & As & $\mathrm{P}$ & $18(7.69)$ & $52(7.1)$ & $\begin{array}{l}\text { Jan, Mar, May, } \\
\text { June, July, Aug, } \\
\text { Nov }\end{array}$ \\
\hline \multicolumn{7}{|l|}{ Caryocaceae } \\
\hline Caryocar brasiliense (Cambess.) & $\mathrm{N}$ & $\mathrm{Se}$ & $\mathrm{S}$ & $61(26)$ & $175(23.9)$ & $\begin{array}{l}\text { Jan, Mar, Apr, } \\
\text { May, June, Nov, } \\
\text { Oct, Dec }\end{array}$ \\
\hline \multicolumn{7}{|l|}{ Combretaceae } \\
\hline Terminalia catappa (Linn.) & $\mathrm{E}$ & $\mathrm{Se}$ & $\mathrm{S}$ & $2(0.85)$ & $5(0.68)$ & Aug \\
\hline \multicolumn{7}{|l|}{ Lecythidaceae } \\
\hline Eschweilera nana (O. Berg.) Miers & $\mathrm{N}$ & $\mathrm{Se}$ & $\mathrm{S}$ & $3(1.2)$ & $7(0.9)$ & Mar, Nov \\
\hline \multicolumn{7}{|l|}{ Leguminosae } \\
\hline Copaifera langsdorffii (Desf.) & $\mathrm{N}$ & $\mathrm{Se}$ & $\mathrm{S}$ & $1(0.42)$ & $1(0.13)$ & Sept \\
\hline Inga laurina (Sw.) Willd. & $\mathrm{N}$ & Ml & A & $6(2.5)$ & $47(6.4)$ & July, Aug, Sept \\
\hline Hymenaea stigonocarpa (Mart.) & $\mathrm{N}$ & $\mathrm{Se}$ & S & $7(3)$ & $23(3.1)$ & $\begin{array}{l}\text { Apr, July, Aug, } \\
\text { Oct }\end{array}$ \\
\hline $\begin{array}{l}\text { Vatairea macrocarpa (Benthan) } \\
\text { Ducke }\end{array}$ & $\mathrm{N}$ & $\mathrm{Se}$ & S & $2(0.85)$ & $6(0.81)$ & Sept \\
\hline \multicolumn{7}{|l|}{ Loganiaceae } \\
\hline Sthrycnos pseudo-quina (A. St. Hil.) & $\mathrm{N}$ & $\mathrm{Se}$ & A & $1(0.42)$ & $4(0.54)$ & Nov \\
\hline \multicolumn{7}{|l|}{ Myrtaceae } \\
\hline Psidium guajava (Linn.) & E & $\mathrm{Se}$ & $\mathrm{P}$ & $7(3)$ & $24(3.2)$ & Jan, Aug \\
\hline \multicolumn{7}{|l|}{ Vochysiaceae } \\
\hline Qualea grandiflora (Mart.) & $\mathrm{N}$ & $\mathrm{Se}$ & S & $20(8.5)$ & $56(7.6)$ & $\begin{array}{l}\text { Apr, Mar, May, } \\
\text { June, July, Aug, } \\
\text { Dec }\end{array}$ \\
\hline Qualea parviflora (Mart.) & $\mathrm{N}$ & $\mathrm{Se}$ & S & $6(2.5)$ & $18(2.4)$ & $\begin{array}{l}\text { May, July, Aug, } \\
\text { Sept }\end{array}$ \\
\hline Total & & & & $234(100)$ & $732(100)$ & \\
\hline
\end{tabular}

records) and $A$. occidentale seeds (51; Figure $1 \mathrm{~b})$. In this season they also consumed palm fruits from $A$. aculeata (8 feeding records) and $S$. oleraceae (7; Table 1$)$.

The variations in the number of plant species available to Blue-and-Yellow Macaws were unrelated to their feeding activity ( $r s=0.41, p=0.18)$. Feeding niche breadth fluctuated substantially with the lowest value in October $\left(B^{\prime}=0.05\right)$, due to the extensive consumption of $A$. occidentale seeds ( $25.2 \%$ of feeding records; Table 1 , Figure $1 \mathrm{c})$, while the highest value occurred in February $\left(B^{\prime}=0.96\right.$, Figure 1c), 

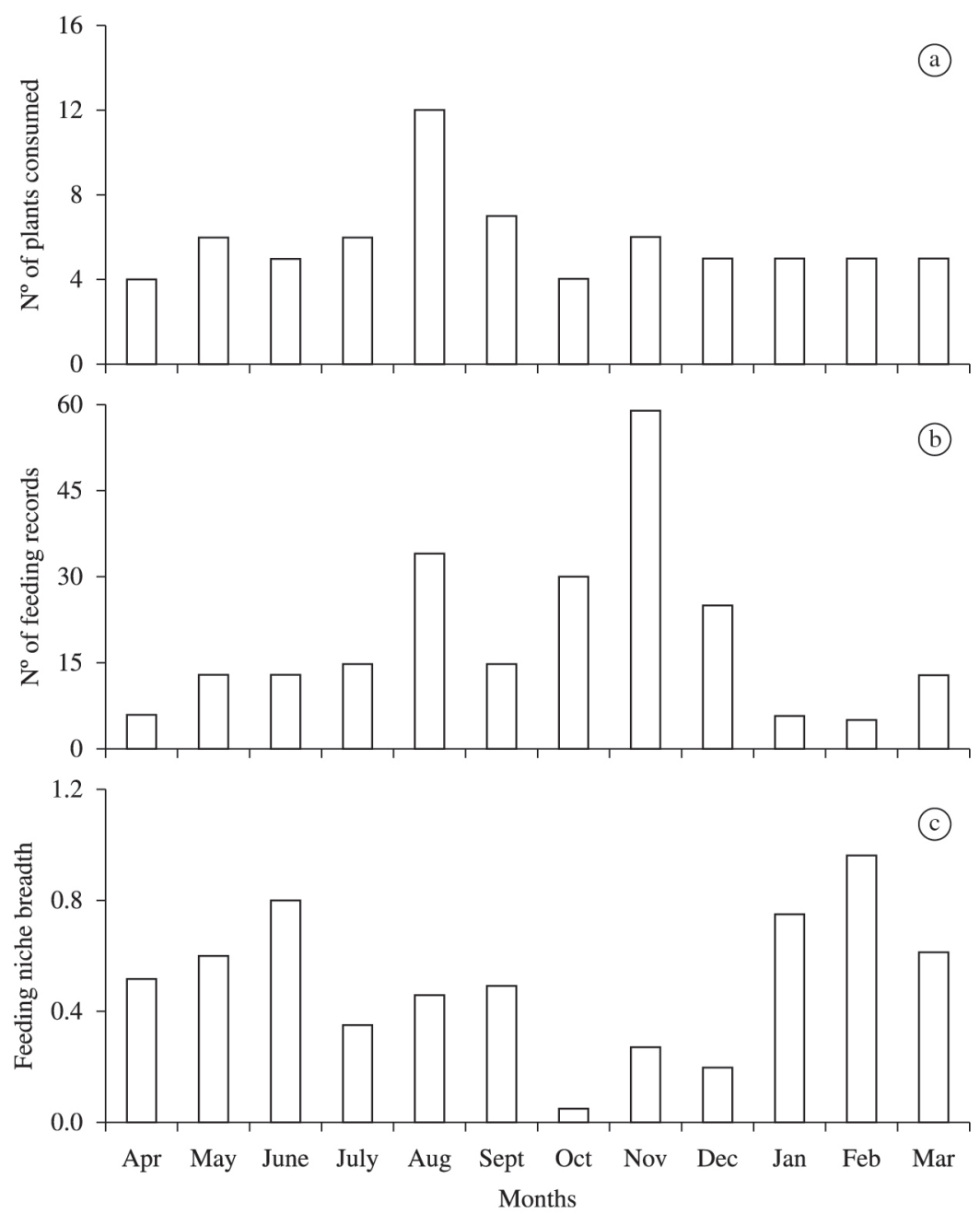

Figure 1. Number of fruit species monthly available to Blue-and-Yellow Macaws (a), feeding records (b), and feeding niche breadth fluctuations (c), in the urban area of Três Lagoas (State of Mato Grosso do Sul, Brazil).

when Blue-and-Yellow Macaws foraged on four species (C. nucifera, A. aculeata, S. oleracea, and Spondias dulcis). Other important peaks occurred in June $\left(\mathrm{B}^{\prime}=0.79\right)$, due to the consumption of $C$. brasiliense, $S$. oleraceae, Q. grandiflora, and A. aculeata, as well as in January $\left(\mathrm{B}^{\prime}=0.75\right)$ when they fed on $C$. brasiliense, $P$. guajava, S. oleracea, S. romanzoffiana, and A. aculeata. In the other months feeding niche breadth fluctuated between $\mathrm{B}^{\prime}=$ 0.2 and $\mathrm{B}^{\prime}=0.62$ (Figure 1c). The fluctuations in feeding niche breadth were strongly and inversely correlated with macaw's feeding activity ( $r s=-0.81, \mathrm{p}=0.001$ ), although exhibited no relationship with the number of plant species available ( $\mathrm{rs}=-0.10, \mathrm{p}=0.75$ ).

Plant species exploited by macaws exhibited a variety of fruiting patterns. We documented a total of 57 feeding records of Blue-and-Yellow Macaws on asynchronous, 171 on seasonal and 6 on fruits from plants with multiple fruiting patterns (Table 1, Figure 2). In this respect, the

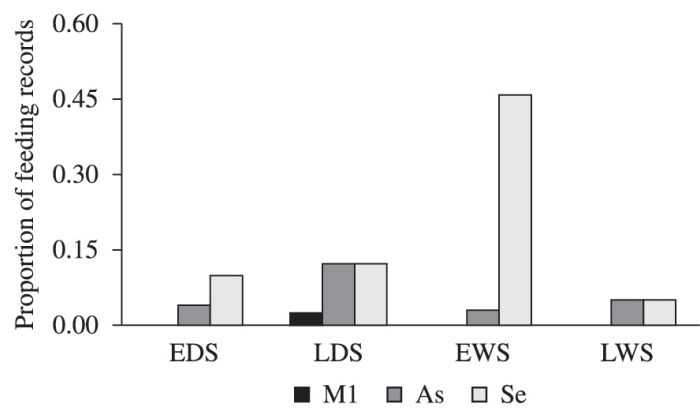

Figure 2. Proportion of feeding records of Blue-andYellow Macaws on fruits from plants with different fruiting patterns during the four periods of the year in the urban area of Três Lagoas (State of Mato Grosso do Sul, Brazil). (Abbreviations follows as: $\mathrm{Se}=$ seasonal fruiting, $\mathrm{As}=$ asynchronous, $\mathrm{Ml}=$ multiple, $\mathrm{Ed}=$ early dry season, $\mathrm{Ld}=$ late dry, $\mathrm{Ew}=$ early wet, $\mathrm{Lw}=$ late wet). 
consumption of seasonal fruits was, at least, twice higher than that of fruits with variable fruiting pattern (asynchronous + multiple). Particularly, Blue-and-Yellow Macaws extensively foraged on asynchronous and multiple fruits in the late dry season, while in the early dry and early wet season they consumed high proportions of seasonal fruits. In the late wet season Blue-and-Yellow Macaws fed on similar proportions of seasonal and asynchronous fruits. Therefore, the amount of asynchronous, seasonal, and multiple fruits highly differed in macaw's diet during the four periods of the year (Chi-square contingency analysis, $c^{2}=64.9, d f=6, p=0.0001$, Figure 2). During the year Blue-and-Yellow Macaws fed much more often on native than on exotic fruit species (217 versus 17 feeding records; Chi-square test, $\mathrm{c}^{2}=2352.9, \mathrm{df}=1, \mathrm{p}=0.0001$; Figure 3). This difference was observed in the four periods of the year (Chi-square contingency analysis, $\mathrm{c}^{2}=12.8, \mathrm{df}=3$, $\mathrm{p}=0.006$, Figure 3).

\section{Discussion}

The Blue-and-Yellow Macaw is yet common in undisturbed areas (Gilardi and Munn, 1998), and cited as the most tolerant macaw to human presence (Ridgely and Greenfield, 2001). Taking into account the adequacy of urban ecosystems as feeding areas for some frugivores (Gasperin and Aurélio Pizo, 2009), the persistence of Blue-and-Yellow Macaws at the studied urban area for feeding purposes is consistent for an opportunistic forager (Collar, 1997; Sick, 1997; Ragusa-Netto, 2006). In this respect, future multi-habitat studies might assess the proportional year round importance of urban areas to Blue-and-Yellow Macaws.

Although many parrot species threatened of extinction have been recorded in areas with modified natural vegetation (Collar and Juniper, 1992), some of them have persisted in the deforestation process, using a mosaic of remnant vegetation according to resource availability (RagusaNetto, 2006; Matuzak et al., 2008). Despite of the fact that anthropogenic activities have been negative to parrots (Novaro et al., 2000; Bodmer and Lozano, 2001), Blue-and-

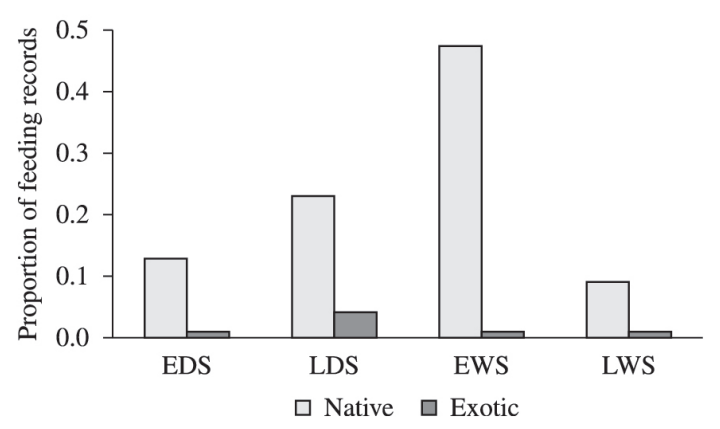

Figure 3. Proportion of feeding records of Blue-and-Yellow Macaws on fruits from native or exotic plants during the four periods of the year in the urban area of Três Lagoas (State of Mato Grosso do Sul, Brazil). (Abbreviations for periods follows as in Figure 2).
Yellow Macaws moved to the urban area of Três Lagoas to exploit a wide range of food items. It is well known that landscape structure, plant community composition and food resources availability could influence bird persistence in urban areas (Marzluff, 2001; Luniak, 2004). Therefore, for a nomadic species as the Blue-and-Yellow Macaw (Collar, 1997; Ragusa-Netto, 2006), the variety of fruit patches dispersed on the city accounted for their presence at this highly anthropized area (Møller, 2009). Moreover, the variety of native and exotic plant species bearing fruits through the year, promotes a permanent food supply favoring the persistence of macaws at Três Lagoas urban area.

At downtown, exotic plant species comprised fruit patches mainly in gardens and squares for ornamental purposes. On the other hand, native trees tend to be common in suburban areas in residence backyards and vacant lots (Pickett et al., 2001). Parrots often fed on exotic food plants during famine periods (Forshaw, 1989; Pitter and Christiansen, 1995). In fact, for example, exotic species with large seeds comprised substantial proportion of the Scarlet Macaw's (Ara macao, Linnaeus 1758) diet at anthropized areas in Costa Rica. There, only two common trees (Cocos nucifera and Terminalia catappa), which fruited all year-round amounted for $48 \%$ of their diet (Matuzak et al., 2008). Nevertheless, Blue-andYellow Macaws seldom foraged on exotic species (less than $10 \%$ of diet). Perhaps this difference resulted from the abundance of native species bearing fruits all year (S. oleraceae, A. aculeata, and I. laurina), while exotic ones, with those traits, were scarce. Native plants dominated the Blue-and-Yellow Macaw's diet and, not surprisingly, most of them produced large fruit crops including large and nutritive seeds. In principle, macaws yet find in the city dense patches of fruit species which they often exploit at natural areas.

Asynchronous fruit resources, especially palm fruits, were among the major foods of Blue-and-Yellow Macaws at the urban area. The extensive consumption of palm fruits, mainly during the dry season, was also noted elsewhere at preserved areas (Roth, 1984; Sick, 1997; Oehler et al., 2001). These nutritive and, potentially, abundant fruits were available when fleshy fruits often decline in tropical areas (van Schaik et al., 1993). Indeed, palm fruiting pattern and its respective use by Blue-and-Yellow Macaws at urban area suggests a keystone role for these plants as observed in tropical forests (Peres, 2000). In fact, the importance of these fruits is particularly pronounced in marked seasonal areas where asynchronous fruits tend to exhibit no redundancy with seasonal fruits (Peres, 2000; Ragusa-Netto, 2010), potentially, the case at the studied urban area. Recently, the reduction of palm density in natural areas has been assumed as the cause of macaw influx to palm orchards (Oehler et al., 2001). In principle, this may be the case in the urban area of Três Lagoas where palms are common due to their ornamental importance. Inga laurina, which also bore fruits several times during the year, is common in squares and gardens to provide shading. When grouped, 
species exhibiting asynchronous and multiple fruiting patterns were very important in providing much of fruits for macaws during the harshest period of the year ( $46 \%$ dry season feeding records, $n=96)$. In this respect, those plants (mainly palms) were associated with a substantial presence of macaws at the urban area, which emphasize their potential for improving the cities as foraging sites.

Despite of the importance of food plants with variable fruiting patters, in general, Blue-and-Yellow Macaws often mostly foraged on seasonal plants species. This was particularly pronounced during the early wet season, when Caryocar brasiliense and Anacardium occidentale were in seed, an item also often exploited by this macaw at preserved cerrado areas (Ragusa-Netto, 2006, 2011; Tubelis, 2009). The large seeds of both species, available during a relatively short period, include high lipid and protein content (Almeida et al., 2008). Surprisingly these seeds comprised $51 \%$ of the Blue-and-Yellow Macaw's diet. Also, at an anthropized area, Scarlet Macaws often fed on large and nutritive seeds, although available all year (Matuzak et al., 2008). Taking into account that Blue-and-Yellow Macaws daily move from communal roosts to feeding areas and vice versa, the high nutritional content of those seeds, presumably, was highly profitable to compensate the costs of daily trips by a large number of individuals (Graham, 2001). These foraging movements are consistent with the prediction that predators focus their activities in areas of enhanced foraging success (Schupp, 1988). In fact, both tree species are also important for humans (Almeida et al., 2008), which might be related to their potential abundance at cities, an additional factor related to the intense exploitation by Blue-and-Yellow Macaws. Moreover, foraging costs at cities may be lower than at natural areas, which, circumstantially, might favor the cities as feeding areas (Chace and Walsh, 2006). It is important to note that Blue-and-Yellow Macaws exhibited significant, although inverse, relationship between their feeding activity and niche breadth values. The factor related to the frequent declines of niche breadth value was the extensive consume of only a seed species at a given month. During the early wet season Blue-and-Yellow Macaws exhibited reduced niche-breadth values, while this parameter fluctuated during the rest of the year according to the combination of seasonal and asynchronous fruits in their diet. Therefore, macaws often extensively foraged on few fruit types regardless of the number of fruiting species. This emphasizes the abundance and nutritional quality of large seeds exploited as a very important factor to attract macaws to the urban area, which is expected for opportunistic frugivores/granivores which search for erratic and massive fruiting patches (Sun and Moermond, 1997; Renton, 2001; Moegenburg and Levey, 2003; RagusaNetto, 2006, 2007b).

The Blue-and-Yellow Macaw presents an important ecological role as pre-dispersal seed predator (RagusaNetto, 2006, 2011), contributing to the maintenance of forest diversity (Janzen, 1970; Dirzo and Miranda, 1990). In spite of that, this bird is currently pressed by the loss and fragmentation of large cerrado areas (Ratter et al., 1997; Carvalho et al., 2009). Although the antropization has been causing the local extinction of a substantial proportion of large-bodied birds (Matuzak et al., 2008), the urban areas could figurate as important feeding sites among a collection of native vegetation remnants (Marzluff, 2001; Luniak, 2004). The adequate management of these areas with an appropriated flora may favor frugivorous birds. Hence, increasing the knowledge on plant species exploited by Blue-and-Yellow Macaws might be important for future conservation plans including the selection of tree species and design of green areas. Actions of this nature will also improve these areas as ecological corridors, an important parameter on animal colonization and occurrence at cities (Fernández-Juricic and Jokimäki, 2001).

Acknowledgements - The authors are grateful to the constructive comments of an anonymous reviewer on an early version of this study. Financial support was provided by FUNDECT, CNPq, and PROPP/UFMS.

\section{References}

ALMEIDA, SP., COSTA, TSA. and SILVA, JA., 2008. Frutas nativas do Cerrado: Caracterização físico-química e fonte potencial de nutriente. In SANO, S.M., ALMEIDA, S.P., and RIBEIRO, JF. (Eds.). Cerrado: Ecologia e Flora, Brasília: Editora Embrapa Informação Tecnológica. p. 351-378. vol. 1.

ANTUNES, AZ., 2009a. Ara ararauna (Linnaeus, 1758). In BRESSAN, P.M., KIERULFF, M C.M. and SUGIEDA, AM. (Orgs.). Fauna ameaçada de extinção no estado de São Paulo: vertebrados. São Paulo: Imprensa Oficial do Estado de São Paulo, p. 162.

ANTUNES, AZ., 2009b. Diopsittaca nobilis (Linnaeus, 1758). In BRESSAN, P.M., KIERULFF, M C.M. and SUGIEDA, AM. (Orgs.). Fauna ameaçada de extinção no estado de São Paulo: vertebrados. São Paulo: Imprensa Oficial do Estado de São Paulo, p. 166.

BIRD LIFE INTERNATIONAL, 2000. Threatened birds of the world. Barcelona and Cambridge, UK: Lynx Edicions and Bird Life International.

BODMER, RE. and LOZANO, EP., 2001. Rural development and sustainable wildlife use in Peru. Conservation Biology, vol. 15 , no. 4, p. 1163-1170. http://dx.doi.org/10.1046/j.15231739.2001.0150041163.x.

BRIGHTSMITH, D. and BRAVO, A., 2006. Ecology and Management of Nesting Blue-and-Yellow Macaws (Ara ararauna) in Mauritia Palm Swamps. Biodiversity and Conservation, vol. 15, no. 13, p. 4271-4287. http://dx.doi.org/10.1007/s10531-005-3579-x.

BULLOCK, SH. and SOLÍS-MAGALLANES, JA., 1990. Phenology of canopy trees of a tropical deciduous forest in Mexico. Biotropica, vol. 22, no. 1, p. 22-35. http://dx.doi. org/10.2307/2388716.

CARVALHO, FMV., DEMARCO, PJ. and FERREIRA, LG., 2009. The Cerrado into-pieces: Habitat fragmentation as a function of landscape use in the savannas of Central Brazil. Biological Conservation, vol. 142, no. 7, p. 1392-1403. http:// dx.doi.org/10.1016/j.biocon.2009.01.031. 
CHACE, JF. and WALSH, JJ., 2006. Urban effects on native avifauna: a review. Landscape and Urban Planning, vol. 74, no. 1, p. 46-69. http://dx.doi.org/10.1016/j.landurbplan.2004.08.007.

COLLAR, NJ. and JUNIPER, AT., 1992. Dimensions and causes of the parrot conservation crisis. In BEISSINGERM, SR. and SNYDER, N. F. R. (Eds.). New World parrots in crisis: solutions from conservation biology. Washington: Smithsonian Institution Press. p. 1-24.

COLLAR, NJ., 1997. Family Psittacidae (parrots). In del HOYO, J., ELLIOT, A. and SARGATAL, J. (Eds.). Handbook of the birds of the world: Sangrouse to cuckoos. Spain: Linx editions Barcelona, p. 280-477. vol. 4.

DIRZO, R. and MIRANDA, A., 1990. Contemporary Neotropical defaunation and forest structure function, and diversity- a sequel to John Terborgh. Conservation Biology, vol. 4, no. 4, p. 444-447. http://dx.doi.org/10.1111/j.1523-1739.1990.tb00320.x.

FERNÁNDEZ-JURICIC, E. and JOKIMÄKI, J., 2001. A habitat island approach to conserving birds in urban landscapes case studies from southern and northern Europe. Biodiversity and Conservation, vol. 10, no. 12, p. 2023-2043. http://dx.doi. org/10.1023/A:1013133308987.

FORSHAW, JM., 1989. Parrots of the world. Sidney: Lansdowne Editions. 672 p.

FUNCH, LS., PUNCH, R. and BARROSO, GM., 2002. Phenology of gallery and montane forest in the Chapada Diamantina, Bahia, Brazil. Biotropica, vol. 34, no. 1, p. 40-50. http://dx.doi. org/10.1111/j.1744-7429.2002.tb00240.x.

GASPERIN, P. and AURÉLIO PIZO, M., 2009. Frugivory and habitat use by thrushes (Turdus spp.) in a suburban area in south Brazil. Urban Ecosystems, vol. 12, no. 4, p. 425-436. http://dx.doi. org/10.1007/s11252-009-0090-2.

GILARDI, JD. and MUNN, CA., 1998. Patterns of activity, flocking, and habitat use in parrots of the Peruvian Amazon. The Condor, vol. 100, no. 4, p. 641-653. http://dx.doi.org/10.2307/1369745.

GRAHAM, CH., 2001. Factor influencing movement patterns of Kell-billed Toucans in fragmented tropical landscape in southern Mexico. Conservation Biology, vol. 15, no. 6, p. 1789-1798. http:// dx.doi.org/10.1046/j.1523-1739.2001.00070.x.

HAUGAASEN, T. and PERES, CA., 2005. Primate assemblage structure in Amazonian flooded and unflooded forests. American Journal of Primatology, vol. 67, no. 2, p. 243-258. http://dx.doi. org/10.1002/ajp.20180. PMid:16229024

HEJL, SJ., VERNER, J. and BELL, W., 1990. Sequential Versus initial observations in studies of avian foraging. Studies on Avian Biology, vol. 13, p. 166-173.

HENDERSON, A., 2002. Evolution and ecology of palms. New York: The New York Botanical Garden Press. 259 p.

JANZEN, DH., 1970. Herbivores and the number of tree species in tropical forests. American Naturalist, vol. 104, no. 940, p. 501-524. http://dx.doi.org/10.1086/282687.

JUSTINIANO, MJ. and FREDERICKSEN, TS., 2000. Phenology of tree species in Bolivian Dry Forests. Biotropica, vol. 2, p. 276-281.

LORENZI, H., 1994. Árvores Brasileiras: Manual de identificação e cultivo de plantas arbóreas nativas do Brasil. Nova Odessa: Editora Plantarum. 384 p. vol. 1.
LORENZI, H., 1998. Árvores Brasileiras: Manual de identificação e cultivo de plantas arbóreas nativas do Brasil, Nova Odessa: Editora Plantarum. 320 p. vol. 2.

LUNIAK, M., 2004. Synurbization - adaptation of animal wildlife to urban development. In SHAW, W.W., HARRIS, L.K. and VAN DRUFF, L. (Eds.). In Proceedings of the 4th International Symposium on Urban Wildlife Conservation. Tucson: University of Arizona, p. 50-55.

MARSDEN, SJ., 1999. Estimation of parrot and hornbill densities using a point count distance sampling method. The Ibis, vol. 141, p. 377-390.

MARSDEN, SJ. and WRIGHT, JL., 2004. Blue-and-Yellow Macaws feeding on soybeans in Brazil's cerrado zone. PsittaScene, vol. 16 , p. 15.

MARZLUFF, JM., 2001. Worldwide increase in urbanization and its effects on birds. In MARZLUFF, J.M., BOWMAN, R. and DONNELLY, R. (Eds.). Avian ecology and conservation in an urbanizing world. Massachusetts: Kluwer Academic Press, p. 19-47.

MATUZAK, GD., BEZY, MB. and BRIGHTSMITH, DJ., 2008. Foraging ecology of parrots in a modified landscape: seasonal trends and introduced species. The Wilson Journal of Ornithology, vol. 120, no. 2, p. 353-365. http://dx.doi.org/10.1676/07-038.1.

MELO, C., OLIVEIRA, AD., BORGES, CA., RIBEIRO, G. and TAVARES, J., 2009. Impact of Forpus xanthopterygius (Spix, 1824) (Aves, Psittacidae) on flowers of Handroanthus serratifolius (Vahl.) S. O. Grose (Bignoniaceae). Revista Brasileira de Biologia = Brazilian Journal of Biology, vol. 69, no. 4, p. 1149-1151. http:// dx.doi.org/10.1590/S1519-69842009000500020. PMid:19967187

MILTON, K., WINDSOR, DM., MORRISON, DW. and ESTRIBI, MA., 1982. Fruiting phenologies of two Neotropical Ficus species. Ecology, vol. 63, no. 3, p. 752-762. http://dx.doi. org/10.2307/1936796.

MOEGENBURG, SM. and LEVEY, DJ., 2003. Do frugivores respond to fruit harvest? An experimental study on short-term responses. Ecology, vol. 84, no. 10, p. 2600-2612. http://dx.doi. org/10.1890/02-0063.

MØLLER, AP., 2009. Successful city dwellers: a comparative study of the ecological characteristics of urban birds in the Western Palearctic. Oecologia, vol. 159, no. 4, p. 849-858. http://dx.doi. org/10.1007/s00442-008-1259-8. PMid:19139922

NOVARO, AJ., REDFORD, KH. and BODMER, RE., 2000. Effect of hunting in source-sink systems in the Neotropics. Conservation Biology, vol. 14, no. 3, p. 713-721. http://dx.doi. org/10.1046/j.1523-1739.2000.98452.x.

OEHLER, DA., BOODOO, D., PLAIR, B., KUCHINSKI, K., CAMPBELL, M., LUTCHMEDIAL, G., RAMSUBAGE, S., MARUSKA, EJ. and MALOWSKI, S., 2001. Translocation of Blue and Gold Macaw (Ara ararauna) into its historical range on Trinidad. Bird Conservation International, vol. 11, no. 2, p. 129141. http://dx.doi.org/10.1017/S0959270901000211.

PERES, CA., 2000. Identifying keystone plant resources in tropical forests: the case of gums from Parkia pods. Journal of Tropical Ecology, vol. 16, no. 2, p. 287-317. http://dx.doi.org/10.1017/ S0266467400001413.

PICKETT, STA., CADENASSO, ML., GROVE, JM., NILON, CH., POUYAT, RV., ZIPPERER, WC. and COSTANZA, R., 2001. Urban ecological systems: Linking terrestrial ecological, physical and socioeconomic components of metropolitan areas. Annual 
Review of Ecology and Systematics, vol. 32, no. 1, p. 127-157. http://dx.doi.org/10.1146/annurev.ecolsys.32.081501.114012.

PITTER, E. and CHRISTIANSEN, MB., 1995. Ecology, status and conservation of the Red-fronted Macaw (Ara rubrogenys). Bird Conservation International, vol. 5, no. 1, p. 61-78. http:// dx.doi.org/10.1017/S0959270900002951.

RAGUSA-NETTO, J., 2004. Flowers, fruits, and the abundance of the yellow-chevroned parakeet (Brotogeris chiriri) at a gallery forest in the South Pantanal (Brazil). Revista Brasileira de Biologia = Brazilian Journal of Biology, vol. 64, no. 4, p. 867-877. http:// dx.doi.org/10.1590/S1519-69842004000500017. PMid:15744428

-, 2005. Extensive consumption of Tabebuia aurea (Manso) Benth. and Hook. (Bignoniaceae) nectar by parrots in a tecoma savanna in the South Pantanal (Brazil). Brazilian Journal of Biology, vol. 65, no. 2, p. 339-344. http://dx.doi.org/10.1590/ S1519-69842005000200018.

-, 2006. Dry fruits and the abundance of the Blue-and-Yellow Macaw (Ara ararauna) at a cerrado remnant in the Central Brazil. Ornitologia Neotropical, vol. 17, p. 491-500.

-, 2007a. Feeding ecology of the Green-cheeked parakeet (Pyrrhura molinae) in dry forests in western Brazil. Revista Brasileira de Biologia = Brazilian Journal of Biology, vol. 67, no. 2, p. 243249. http://dx.doi.org/10.1590/S1519-69842007000200009. PMid:17876434

-, 2007b. Nectar, fleshy fruits and the abundance of parrots at a gallery forest in the southern Pantanal (Brazil). Studies on Neotropical Fauna and Environment, vol. 42, no. 2, p. 93-99. http://dx.doi.org/10.1080/01650520600979643.

-, 2008a. Toco Toucan (Ramphastos toco) feeding ecology and local abundance in a habitat mosaic in the Brazilian cerrado. Ornitologia Neotropical, vol. 19, p. 345-359.

-, 2008b. Yellow-Chevroned Parakeet (Brotogeris chiriri) abundance and canopy foraging at a dry forest in western Brazil. Studies on Neotropical Fauna and Environment, vol. 43, no. 2, p. 99-105. http://dx.doi.org/10.1080/01650520701510859.

-, 2010. Figs and the persistence of Toco Toucan (Ramphastos toco) at dry forests from western Brazil. Ornitologia Neotropical, vol. 21 , p. 59-70.

-, 2011. Pre-dispersal seed predation by Blue-and-Yellow Macaw (Ara ararauna, Psittacidae), on fruit crops of the Pequi (Caryocar brasiliense, Caryocariaceae), in the Brazilian cerrado. Ornitologia Neotropical, vol. 22, p. 329-338.
RAGUSA-NETTO, J. and SILVA, RR., 2007. Canopy phenology of a dry forest in western Brazil. Revista Brasileira de Biologia = Brazilian Journal of Biology, vol. 67, no. 3, p. 569-575. http:// dx.doi.org/10.1590/S1519-69842007000300024. PMid:18094842

RATTER, JA., RIBEIRO, JF. and BRIDGEWATER, S., 1997. The Brazilian Cerrado vegetation and threats to its biodiversity. Annals of Botany, vol. 80, no. 3, p. 223-230. http://dx.doi.org/10.1006/ anbo.1997.0469.

RENTON, K., 2001. Lilac-crowned Parrot diet and food resource availability: resource tracking by a parrot seed predator. The Condor, vol. 103, no. 1, p. 62-69. http://dx.doi.org/10.1650/00105422(2001)103[0062:LCPDAF]2.0.CO;2.

RENTON, K. and BRIGHTSMITH, DJ., 2009. Cavity use and reproductive success of nesting macawsin lowland forest of southeast Peru. Journal of Field Ornithology, vol. 80, no. 1, p. 1-8. http://dx.doi.org/10.1111/j.1557-9263.2009.00198.x.

RIDGELY, R. and GREENFIELD, P., 2001. The birds of Ecuador. New York: Cornell University Press. 768 p.

ROTH, P., 1984. Repartição do habitat entre psitacídeos simpátricos no Sul da Amazônia. Acta Amazonica, vol. 14, p. 175-221.

SCHUPP, EW., 1988. Seed and early seedling predation in the forest understory and in tree fall gaps. Oikos, vol. 51, no. 1, p. 71-78. http://dx.doi.org/10.2307/3565808.

SICK, H., 1997. Ornitologia Brasileira. Rio de Janeiro: Nova Fronteira. $912 \mathrm{p}$.

SUN, C. and MOERMOND, TC., 1997. Foraging ecology of three sympatric turacos in a montane forest in Rwanda. The Auk, vol. 114, no. 3, p. 396-404. http://dx.doi.org/10.2307/4089241.

TRIVEDI, MR., CORNEJO, FH. and WATKINSON, AR., 2004. Seed predation on Brazil nuts (Berthollethia excelsa) by macaws (Psittacidae) in Madre de Dios, Peru. Biotropica, vol. 36, p. 118-122.

TUBELIS, DP., 2009. Feeding ecology of Ara ararauna (Aves, Psittacidae) at firebreaks in western Cerrado, Brazil. Biotemas, vol. 22 , p. 99-109.

VAN SCHAIK, CP., TERBORGH, JW. and WRIGHT, SJ., 1993. The phenology of tropical forests, adaptive significance, and consequences for primary consumers. Annual Review of Ecology and Systematics, vol. 24, no. 1, p. 353-377. http://dx.doi. org/10.1146/annurev.es.24.110193.002033. 